\title{
Isaiah 5: A prophetic critique of economic proportion
}

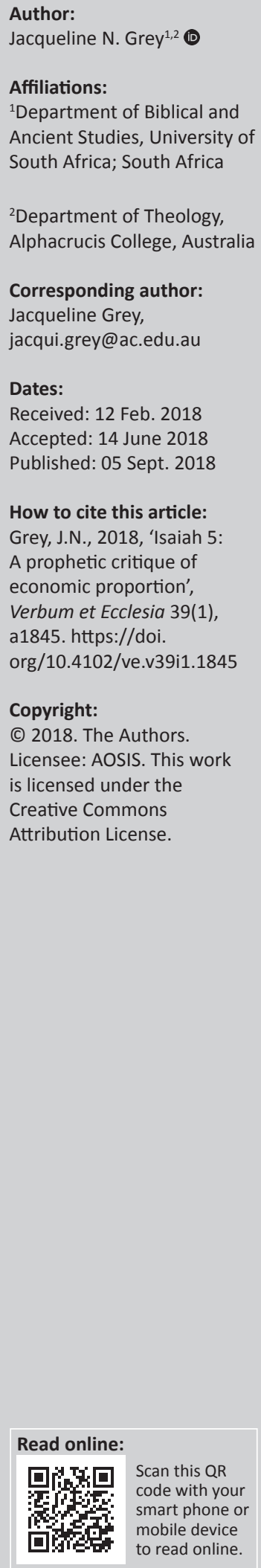

The text of Isaiah 5 describes a rapidly changing society in 8th-century BCE Judah. This shift is driven by forces such as increased international trade, the clash of urbanisation and agrarianism, and the rise of the urban elites. These changes have direct correlation with the transforming economic environment of that period. Yet scholars have paid little attention to the economic realities reflected in the message of the prophet Isaiah. This article explores the context of Isaiah 5 through an engagement with economic theory. While recognising the dilemmas in the adoption of tools from contemporary economic theory to analyse an ancient society, this article utilises game theory to shed light on the historical and cultural background to the text. By applying the 'prisoner's dilemma' it explores the 'deal' being offered by the prophet to the Judahite leaders in Isaiah 5: 8-24. In particular, the article looks at rational choice and the selfinterested basis of decision-making to draw insights from the text by highlighting the conflicts of interest for the wealthy elite of Isaiah 5 .

Intradisciplinary and/or interdisciplinary implications: This research relates to the disciplines of Old Testament Studies and Economic Theory. The focus is applying economic theory to the biblical text of Isaiah 5 .

\section{Introduction}

The text of Isaiah 5 describes a situation of international trade, opulent lifestyles for the wealthy and the marginalisation of the poor in Judah in the 8 th century BCE. ${ }^{1}$ Yet scholars are divided in their understanding of the economic environment of that period. This article explores the context of Isaiah 5 through an engagement with economic theory. In one sense, this article is an attempt to bring together the two seemingly disparate voices of biblical studies and economics. These two disciplines represent two very different fields of enquiry - different discourses - and therefore ask different questions of the text. Therefore, a proposed dialogue with these two partners immediately raises a concern over the appropriateness of the engagement. Is economics an appropriate dialogue partner with biblical studies? The most obvious objection to this proposed dialogue is the historical distance: the world of the biblical text (especially a text from 8th-century BCE Judah) is seemingly incompatible with the contemporary world of economic theory. Economics assumes a developed market economy, whereas the biblical world of 8th-century Judah was a simple agrarian society. Yet this very description of 8th-century Judah is a reflection of the geopolitical economy of the region at that time. Both disciplines, then, have a common interest in understanding and analysing the forces that have shaped societies, albeit across historical and cultural distances. In fact, some scholars have been exploring evidence from the biblical text and archaeological findings for the existence of markets in ancient Judah and ancient Israel, even in their primitive form. However, on a broader level, the legitimacy of some level of dialogue can be found on the basis of postmodern historiography in which two voices that speak across historical and cultural divides can be bought together in dialogue to see what sparks, as Fernando Segovia (1999:188) expresses it, are generated in the process. If nothing else, economic exploration may simply cause us to ask new questions of the text.

This study then is an experiment to see the sparks that have and can generate from the dialogue of biblical studies and economics through a reading of Isaiah 5. It will first consider the existing conversation among key Isaian scholars regarding the economic situation of Isaiah 5. The current

\footnotetext{
An 8th-century date for Isaiah 5 is well attested in current scholarship, albeit recognising some later redactional activity that has produced a multilayered text is inevitable. While some scholars, such as Kaiser (1983), argue against an Isaianic core to the text and produced a multilayered text is inevitable. While some scholars, such as Kaiser (1983), argue against an Isaianic core to the text and
some (such as Sweeney 1996) emphasise the import of the late-seventh-century redactions, other scholars such as Barton suggest that some (such as Sweeney 1996) emphasise the import of the late-seventh-century redactions, other scholars such as Barton suge
these are core passages that most likely reflect authentic Isaianic material. In fact, Barton (1995) writes of Chapter 5 that

virtually everyone thinks that the "Song of the Vineyard", a clever denunciation of the social injustices in Jerusalem (5.1-7), the "woes" with their distinctive interpretation of the failings in Judean society (5.8-25), and the prediction that the merciless Assyrian army will one day invade Judah (5.26-30), are a genuine record of Isaiah's own message. (p. 21)

See J. Barton, Isaiah 1-39, Sheffield: SAP.
} 
dialogue is focused on the debate over interpreting the archaeological and biblical records to understand and describe the economic background of Judah in the 8th century BCE. Scholars such as Chaney (1999) and Premnath (2003) argue for a massive and disruptive social change during this period; others such as Williamson (2006) are more moderate in their interpretation. In one sense, this conversation is at an impasse; until there is further significant archaeological work completed the conversation can only be repetitive. However, surely the field of economics can offer more than just a descriptive analysis of an ancient economic system? Perhaps by applying other theories from economics, which may cause us to ask different questions of the biblical text, new ideas can be generated, not as facts but as possible theories to assist in understanding the text. This article, then, will apply a contemporary theory of economics, that is, the prisoner's dilemma from game theory, to ask new questions and see if some sparks are produced for the purpose of gaining further clarity on this ancient text and its implications for today.

\section{Exploring Isaiah 5:1-24}

Isaiah 5 commences with the Song of the Vineyard. The Song of the Vineyard (5:1-7) points to the economic reality of 8th-century BCE Judah through the imagery of viticulture. The concern of the prophet, in the midst of economic and social change, was for those vulnerable within society. While there are various suggestions as to the genre of this passage, including that of a juridical parable and a funeral song, ${ }^{2}$ most identify it as a 'love song ${ }^{3}$ by its use of language such as dôd (beloved) in v. 1 (Couey 2015:161). Yet the love song 'turns out to be a complaint' (Childs 2001:45). The owner of the vineyard has invested a considerable sum in developing the venture into viticulture. The owner has used the best raw materials (excellent soil and the choicest vines) and has installed the best technology (watchtowers and vats). A substantial return is anticipated from this investment. However, the vineyard only produces bitter grapes that are unusable for wine (Childs 2001:45). Couey notes the precise detail and technical vocabulary used by the prophet in describing the production of this vineyard. The entire scope of the process is described (2015:161). However, as the song continues, it becomes clear that this vineyard refers to Judah and Israel. Instead of producing a harvest of justice, they have produced bloodshed. Instead of yielding righteousness, they have produced a cry of pain from the people who are being treated unfairly and oppressively. As Goldingay notes, ironically this same term is used to describe the crying out of Israel in Egypt but is now used against one another (2014:22).

What then follows is a list of 'woes'; these woes describe the exploitation of the poor and marginalised by the wealthy and powerful. Isaiah reminds the leadership of Judea, through these 'woe oracles' (5:8-30), of their responsibility to those to

2.According to John Watts, the setting of Isaiah 5 is that of a funeral, mourning the announced demise of the northern kingdom (2005:60).

3.Blenkinsopp (2000:206). However, Childs strongly emphasises that it is not a love song but 'a song of a beloved one concerning his vineyard that is sung by another' (Childs 2001:45). whom they have denied justice. It is a view held by many commentators that the six woe oracles of verses 8-24 have a separate origin to the Song of the Vineyard in verses 1-7 (Williamson 2006:345). ${ }^{4}$ Despite that, virtually all commentators agree that the basic woe sayings originate with Isaiah and that the major concerns reflected in the passage are consistent with a number of other 8th-century passages, grounding it quite conclusively in that period of the 8th century BCE. The chapter moves from a general indictment against the nation of Judah in the Song of the Vineyard to a specific indictment against a particular segment of the society in verses 8-24. For example, the first woe is against those who add house to house and join field to field. ${ }^{5}$ So the audience of the two sections of the book are likely to be slightly different as it moves from addressing the whole nation to just one portion of the society (Williamson 2006:346). This indictment is against the wealthy, who are taking advantage of the poor to procure their land for the building of great estates. According to Roberts (2015:78), this situation was exacerbated by the influx of cheap labour of the landless refugees from Israel seeking refuge in Judah after the disaster of the Syro-Ephraimitic War (735-732 BCE). ${ }^{6}$ The leaders of Judah, as verse 12 indicates, sought a hedonistic lifestyle. Roberts writes, 'Judah's leaders in their intoxication with pleasure have lost the ability to discern God's work' (2015:81). They exhibit little concern for the crying out of those they have oppressed.

This stinging critique of 8th-century BCE Judah by the prophet Isaiah continues until verse 30 . These woes describe both theological concerns as well as connected issues of economic injustice. However, it must be asked: to whom are the economic abuses attributed? Who are these perpetrators? And what exactly did they do wrong? At this point, most commentators are quite vague. As Coomber (2011:398) notes, while the intended audience may have been privy to the motivations behind the land seizures that the passage directly refers to and the identities of the perpetrators and victims, these remain hidden from the contemporary reader. While commentators such as Brueggemann (1998) and Watts (2005) note that sections within the chapter address the issue of land tenure as well as more general injustices, they generally do not identify the perpetrators. Instead, Watts highlights the sacred right of the tribal communities to land and the prohibitions against selling it (see Lev 25:33 and 1 Kings 21). He writes, 'When these ordinances gave way to the greed of speculators, it created a class of landless unemployed without home, livelihood, or civil rights' (2005:60). According to Brueggemann, the woe utterances of Isaiah 5:8-25 convey a mood of sadness and mourning for the anticipated demise

4.As Williamson (2006) notes, some scholars have even emphasised the mysterious absence of a seventh woe oracle in Chapter 5, suggesting that it was moved by a redactor to either Chapter 1 or 10 . He also notes that the woe is often thought to date from early in Isaiah's ministry. However, other commentators have suggested that it comes from a slightly later date during Hezekiah's reign and reflects the support of the wealthy elite in preparing for Hezekiah's revolt against the Assyrians, which Isaiah opposed.

5.Note that Micah presents a similar oracle against the same people in Micah 2:1-6.

6.It is noted that the literary context of Isaiah 5 , as part of the framework of the muchdebated Denkschrift (or, as Sweeney suggests, as part of a block of Chapters 5-12 debated Denkschrift (or, as Sweeney suggests, as part of a block of Chapters 5-12;
Sweeney 1996), emphasises the prevalent concern of Assyrian invasions and judgment. 
of those that have behaved 'in such unacceptable ways' (1998:51). He describes the unacceptable practice, identified from the first woe, as 'an inequitable economic practice in which those who are prosperous, aggressive, and greedy eventually confiscate and possess the houses and fields of their more vulnerable neighbors' (1998:51). Brueggemann writes, 'This economic procedure, which destroys the neighborly fabric of the community, apparently was widespread in 8th-century Judah and was regarded by the prophets as a grave violation of Yahwism' (1998:51). Brueggemann later identifies (from verse 14) these perpetrators as the 'nobility'. Apart from these vague identifications, commentators have generally provided no further insight. Therefore, scholars have looked to other methods and theories to try and identify these perpetrators of Isaiah 5, including social-scientific approaches.

\section{The economic world of Isaiah $\mathbf{5}$}

As noted above, a significant development in understanding the economic situation of the text has been offered by Premnath and Chaney. Premnath utilises a social-scientific approach to explore the functions and systems within the social fabric of 8th-century Judah. He focuses particularly on the development and processes of latifundialisation, or land accumulation in the hands of the minority wealthy elite (2003:1). The control of land was vital to an agrarian society as it represented the primary economic base. In the 8th century, land ownership was increasingly centralised along with the agricultural outputs. Rather than follow the traditional method of agricultural diversity to minimise risk, what emerged in this period was a centralised agricultural economy by which lands were consolidated for intensified crop production and specialisation (Glass 2000:30). While this increased risk, it also potentially increased profit through the development of international trade in luxury items, particularly the products of Judah's viticulture, such as wine. So, it is no mistake that the Beloved of Isaiah 5 plants a vineyard; according to Premnath, this was a specialised crop at this time that was increasingly developed for the thriving wine industry (2003:94). The development of latifundia was most likely because of foreclosures of land previously belonging to peasants. Left landless, they then sought work as hired labourers. The perpetrators are identified by Premnath as the ruling elite. Coinciding with the economic growth in the 8th century was the centralising of power by the monarchy. This resulted in the concentration of power in the hands of a few. This ruling minority benefitted from the situation as they extracted an economic surplus, thus allowing increased engagement in international trade. As the ruling elite amassed wealth, the situation of the peasantry who made up the majority of the population deteriorated (Premnath 2003:43). It is to this situation, according to Premnath, that Isaiah 5 speaks.

This perspective is similarly explored by Chaney. Focusing on the political economy of viticulture in 8th-century Judah, Chaney highlights the polemic nature of Isaiah's Song of the Vineyard. This polemic is voiced in a period of rapid economic development and agricultural intensification (1999:106). Therefore, the topic of vineyards and drinking wine and living in large estates selected by the prophet was not neutral but instead loaded with implication. To obtain land and dislocate the majority population, Chaney suggests that the minority elite controlled the legal systems, taxation and state policies - and that they utilised these systems to gain control of peasant farmlands, thus creating their latifundia or large estates (Chaney 1999:107). Land that had previously been used for multiple purposes and diverse crops was converted for specialised crops, such as the vineyard of the Beloved in Isaiah 5:1-7. Chaney cites archaeological evidence for the intensification of wine and oil production in the hill country of Judah. While difficult to date, Chaney suggests that there is solid evidence for innovations from this period such as watchtowers, terracing and new rock-hewn winepresses. However, for Chaney, the real issue for the prophets was that the wealthy elite were acquiring through legal but underhanded means the hereditary lands of the majority population. The land that the majority peasantry had owned for generations was sold - as Chaney writes 'many now worked land that had been in their families for generations, but they worked it as land-less day laborers' (1999:109). The shift in the social stratification of the society into the minority elite and majority poor is reflected in the economic gap, which was significant. Chaney posits that the minority elite, which comprised approximately $2 \%$ of the population, controlled and exploited the rest of the population (Chaney 1986:56, 72-73).

This picture of the greedy elite in 8th-century Judah painted by Chaney is reinforced by his form-critical study of the Song of the Vineyard. Chaney identifies the passage as a juridical parable, which generally concerned a royal figure (1999:111). Beyond the king then, it must be asked: who benefitted from this economic prosperity? According to this theory, it was the urban-based landowners who benefitted most from this growth (Glass 2000:31). Thus, the indictment of the Song of the Vineyard was against the ruling elite or ruling dynasty and not the general population (Chaney 1999:115). It is this same group who ruled the political economy of Judah who are identified, according to Chaney, as the perpetrators of Isaiah 5:8 through their greedy acquisition of land and creation of latifundia. The processes of latifundialisation and crop specialisation provided the environment for what Glass (quoting Lang) calls 'rent capitalism' (2000:30). This eroded village life by dividing each segment of the process of producing agricultural goods. Interestingly it is this process that the Song of the Vineyard describes. It also contributed to poverty because rents or taxes could be exacted for each segment of the process of production. What resulted was a tax or rent on each phase of production (Glass 2000:30). This had the effect of undermining the self-sufficiency of small farmers as they were increasingly undertaking risky enterprises of specialising on one component of production, meaning that they were reliant on its purchase by the wealthy. 
According to Lang, this also increased the social stratification between the urban-based absentee landowners and the rural-based hired labour force. This situation enabled the urban elite to dictate market resources and prices, most probably encouraged or even aided by the trade and taxation policies controlled by the royal elite to which they belonged. There is certainly evidence for this theory. For instance, drawing on the work of Eitan-Katz, Faust notes that there has been identified in the archaeological record from Judah in these centuries various branches of economic specialisation, especially in the field of agricultural production. However, for Faust, while this transition may have commenced in the 8th century with signs of a transition from a family-based economy in that period, it was only in transition at that time, with the development into a centralised, royal economy being realised in the 7th century (Faust 2012:31,37).

\section{Latifundia}

While Williamson describes the socio-economic situation of verse 8 as referring to '... the inappropriate accumulation of landed wealth by a privileged minority', from here, Williamson admits to being less certain as to the identity of the perpetrators. The possibilities of this socio-economic situation have been numerous, including the following options. Firstly, latifundialisation as posited by the likes of Chaney and Premnath. As noted, latifundialisation is the development of large estates in which the former small landowners were reduced to become hired labourers or slaves through foreclosure on mortgages (Williamson 2006:351). A second alternative, according to Williamson, is that this refers instead to a modest acquisition of land. Modest land acquisition refers to the situation 'in which the small farmers remained on their holdings but were obliged to pay over much of their produce to the new owner'. According to Williamson, this also occurred through the manipulation of mortgages. The third option is the utilisation by the wealthy of properties. In this theory the land ownership itself did not transfer, but the rich were holding the property as a pledge against a loan and were able to enjoy and inhabit it, as a kind of common habitation. The final option explored by Williamson was fourthly that of an extended family dispute. As an extended family dispute, the injustices described were not experienced on a large scale but were localised, representing more of a description of inequalities within a village or extended family where more powerful members exploited the weaker. ${ }^{7}$

According to Williamson, there is insufficient evidence to prioritise one of these possibilities over another. In fact, Williamson rejects as least likely what he describes as the two extremes, that is, the suggestion of latifundialisation posited by Premnath and Chaney and the extended family dispute theory. Williamson (2006) suggests that there is no evidence

\footnotetext{
7The term 'latifundialisation' was introduced to Isaian studies by Premnath. While the term originally was used to describe a phenomenon dating from Roman times, it is used in social-scientific literature to refer to 'the process of land accumulation... it is used in social-scientific literature to refer to 'the process of land accumulation ....
in the hands of a few wealthy landowners to the deprivation of the peasantry' (p. 49). See Premnath (1988).
}

for latifundialisation being practised on a wide scale. He writes:

Had small landowners being reduced to slavery in the service of large estates been a common occurrence, we should certainly have expected references to it to surface more explicitly among the many prophetic diatribes against the sorts of practices condemned here. (p. 352)

Williamson observes that the archaeological evidence for either widespread latifundialisation or extended family dispute is not clear. He suggests that there certainly is evidence for latifundia (or large estates) but not of the endemic proportions suggested by Premnath. Instead, the latifundia were restricted to the marginal areas of Judah (possibly referring to the development of royal estates in the Shephelah and fringes of the Judean wilderness, of which there is archaeological evidence) and not affecting the bulk of the population in the Judean heartland (2006:352). Therefore, he suggests that the perpetrators were more interested in acquisition of the produce of the land, by which they could be further enriched, than in the ownership of the land or property in and of itself.

Williamson also challenges the explanations for the development of this situation that suggest a rise in economic prosperity of the region in the 8th century combined with the increasing centralisation of the royal administration, resulting in a kind of pre-industrial capitalism. He argues that the evidence for this economic boom is not as robust as had been previously supposed and that the archaeological evidence cited by the likes of Chaney and Premnath is not so clear (2006:352). Again, he looks to alternative possibilities. He suggests that this situation refers specifically to royal officials wanting to increase crown land, which had been granted to them by the king. They used their positions and power of developing new decrees to legalise their claims to property on behalf of the crown (2006:353). An earlier possibility, offered by Holladay (1998), suggested that the increased Assyrian control of the area meant a reduction in the royal income by trade tariffs. This meant that the primary revenue of Judah was internal, resulting in increased pressure and reliance upon the domestic income to meet the international tribute payments and fund the royal administration (Williamson 2006:353). Therefore, the opposing theories of Williamson and Holladay suggest a more stable period of growth in which exploitation of the poor was perpetrated by the wealthy elite because of domestic pressure on the economic system, rather than to extend the growth of trade for profit's sake. Like Chaney, Williamson suggests that the injustice was not technically illegal (as emphasised by the condemnation in 5:23) but went against the sense of justice of the prophet. These differences in approaches to understanding the socio-economic realities of 8th-century Judah are not only the result of different methodologies but also different analysis of the data.

Finally, weighing most recently into this debate over the economic situation of 8th-century Judah is Faust, with his analysis of the archaeological findings from 7th- and 
8th-century Judah and Israel. His interpretation of these archaeological findings shows that in the cities of the kingdom of Judah there were clear socio-economic differences within the population, as reflected in Isaiah 5. However, the economic differences were confined to the cities and not the rural populations; though still clearly there were some more wealthy than others, these differences were not as significant in the rural sector, which maintained its more traditional lifestyle. Faust (2012) writes:

An analysis of the settlements shows that at the end of the eighth century BCE there were usually only two classes in Judahite cities (except for in Jerusalem, particularly in the seventh century $\mathrm{BCE}$ ): a lower class including the vast majority of the population (composed of various groups of course), and a very limited upper class of the very rich. (pp. 115-116)

He suggests that a narrow section of the society of 8th-century Judah was the wealthy elite, while the rest of the majority population was in a much worse economic condition (2012:32), thereby confirming significant social stratification in 8th-century Judah - but that this stratification was only located in the cities and urban settlements. Faust writes, 'The stratification did not occur in the entire social system but was limited mainly to the urban sector' (2012:270). Therefore, areas such as the Shephelah, which Williamson had noted for its possible latifundia, are described by Faust as having experienced little social change during this time. Faust writes, 'Regarding the rural sector, those who argued that this was a traditional, family-oriented, autonomous society were probably right' (2012:271).

According to Faust, the rural regions of Judah maintained their broader kinship structure (tribe, clan and family) and continued as before during this period. However, within the urban centres, there was significant social stratification; this stratification and increased urbanisation had a significant impact upon the social fabric of the society that led to changes in the family structure and social organisation. He suggests that the basic economic unit at this time in the urban centres was the nuclear family. He writes of the cities and urban settlements of this time that 'The economic system was staterun or private (at the nuclear family level), and there is no indication of any intermediate level' (2012:113). This meant that in these urban centres many of the legal systems and authority traditionally and previously held by the elders were gradually subsumed by the monarchy (2012:263). This interpretation of the data by Faust provides yet another perspective on this attempt to reconstruct the socio-economic realities of this period. Each scholar interprets the data differently and arrives at a different conclusion in their description of the economic background of Judah in the 8th century BCE. At this point in the conversation, understanding the economic reality of this period is at an impasse until either further archaeological evidence is uncovered or consensus on the interpretation of the current data is achieved. So where does that leave us in this dialogue between biblical studies and economics? Perhaps another approach is needed. As has been suggested, another tactic may be to explore the application of contemporary theories of economics. The purpose of this approach is to see if any synergies emerge that can aid the understanding of the economic reality of this period.

There has been a measure of success already in this approach. Coomber (2011) recently applied cultural-evolutional theory to a study of Isaiah 5 to explore possible motivations by the prophet for his complaints against land ownership abuse. He compares the patterns of modern-day Tunisia and ancient Judah through the shared experience of agrarian challenges and a religious-based system of land management that is threatened by the changing economic strategies of the state (2011:415). Coomber observes that those traditional religious practices that do not support new economic strategies tend to be overturned during transitional periods to support the new economic environment. He noted the self-interest of religious leaders, who in defending the traditional practices were sometimes defending against their own marginalisation in a changing society (2011:396). Applying this culturalevolutional theory to Isaiah 5, he suggests that the prophet may have also been defending his own role within the changing society. He writes (Coomber 2011):

At the risk of appearing cynical toward those who would employ prophetic complaints against injustice in struggles against injustice, I would like to propose that prophetic complaints against landownership abuse might have been inspired as much by the displacement of the prophetic authors, themselves, as they were by the displacement of Judean farmers. (p. 424)

He goes on to suggest that while the self-interest of the prophet may have been a motivating factor it does not devalue the complaint expressed against the economic injustices. The changes in 8th-century Judah precipitated by the economic and agricultural strategies of the powerful wealth-holders would not only have had an impact on the social fabric but also religious institutions of the society. Coomber surmises that perhaps the complaints of Isaiah against the Temple activity in Isaiah 1:10-13 reflects the anger of those who lost their regional worship sites through the urbanisation process and centralisation of worship in the Jerusalem Temple (2011:425). While Coomber rightly highlights the possibility of self-interest, if not at least mixed motivations, in the actions of many leaders and prophets, it is more likely that the mixed motivation of Isaiah is a combination of concern for the urban poor but also possibly a protest voiced against this economic hardship as a product of Hezekiah's preparations for revolt against Assyria. ${ }^{8}$ That is not to say that Isaiah is without self-interest; however his location in Jerusalem and outside the priestly service would make Coomber's suggestion less likely. However, what Coomber successfully achieves in his application of culturalevolutional theory is to provide a model of approaching an ambiguous text like Isaiah 5 from a fresh perspective. I would like to now follow Coomber's example and offer a possible avenue for further exploration of Isaiah 5 using a specific approach within economic theory, that of game theory.

8.See also Williamson 2006:353 


\section{Prisoner's dilemma}

For the purpose of generating some sparks, game theory is explored to see what questions it raises that might be helpful in examining the biblical text. Game theory has been utilised in biblical studies more generally by Brams (2003) through an analysis of biblical narratives. Game theory, as King (2007) notes:
... asks how and why people (and animals) make individual decisions in a social context. It starts from the observation that conflicts of interest must arise in all groups of independent individuals, from coral polyps to people; it assumes that all sides in a conflict will act primarily in their own self-interest; and it searches for rational solutions. (p. 28)

While this definition is very general, a possible approach is to read Isaiah through the lens of the prisoner's dilemma scenario, one of the basic forms of game theory. In the prisoner's dilemma game, for example, two people (A and B) have been arrested for burglary and placed in separate cells. The detective then tries to get them to inform on each other by involving them in a kind of game by offering them the same deal. The deal involves three options. The first option is that if only one of them informs on the other and the other is silent then the informant can go free and the silent one will be charged and receive the maximum sentence. The second option is that if they both inform on each other, then they will both be charged but not receive the maximum sentence. In option 3, if both remain silent then both may be convicted. However, this third option is not determined - while they may both be charged they may not actually be convicted and so may actually get off free and keep the rewards of their alleged burglary. The challenge of the prisoner's dilemma is trying to select the option that has the least risk and the most benefit to the individual.

\section{Consider, then, the 'deal' being offered in Isaiah 5:}

Woe to you who add house to house and join field to field till no space is left and you live alone in the land. The Lord Almighty has declared in my hearing: 'Surely the great houses will become desolate, the fine mansions left without occupants. A ten-acre vineyard will produce only a bath of wine; a homer of seed will yield only an ephah of grain' (vv. 5-10).

Suppose that Isaiah 5:8-10 is heard by persons A and B, who are part of the wealthy elite. Imagining Isaiah 5 through this game, then, the prophet presents them with these options: If A discontinues her or his unjust practices and B continues them, then A may have a good harvest but may not make a profit, as operating justly may not result in a profit from the final product; however, the victims are given justice. Person B will not have a good harvest but may still make a profit due the unjust practices because the poor will pay for the lost harvest through taxation and recovered mortgages. The person from the wealthy elite (person B) is not individually affected by the threat, so if unmoved by the moral and ethical argument is unlikely to change her or his behaviour as a result of Isaiah's deal. Assuming that Faust's analysis of the social stratification of the urban centres is correct and that urbanisation during this period resulted in a breakdown of traditional social organisation based on the kinship structure (tribe, clan and family), then these marginalised poor were not considered kin by the wealthy elite but were outside the responsibility of family. On a rational and self-interested basis, the wealthy elite person is unlikely to cooperate. The option most likely to be selected by the wealthy elite person (assuming they are motivated by self-interest) is unlikely to be the response desired by the prophet. What should the prophet do? The prophet should then change the options of the deal to increase the likelihood of the wealthy elite persons changing.

If social concerns do not motivate the wealthy elite persons to change their greedy ways, then the prophet should address the inherent self-motivation, which we see is exactly what the prophet does in Isaiah 5:

Woe to those who rise early in the morning to run after their drinks, who stay up late at night till they are inflamed with wine. They have harps and lyres at their banquets, pipes and timbrels and wine, but they have no regard for the deeds of the Lord, no respect for the work of his hands. Therefore my people will go into exile for lack of understanding; those of high rank will die of hunger and the common people will be parched with thirst. (vv. 11-13)

This certainly changes the options! So, the deal now is option 1: if A discontinues the unjust practices and B continues them, then A may have a good harvest but may not make a profit, and B will not have a good harvest but may still make a profit because of the unjust practices; however, both the wealthy elite persons A and B will individually suffer through the devastation of exile along with the majority of the population (that is, the victims of their injustice). So regardless of person A changing his or her ways, both A and B will personally suffer. Yet person B may enjoy her or his profits until the threatened exile occurs or may even be tempted to try and utilise their profits in alleviating some of the pain of the exile, which person A may not be able to do as they have given up their profit. However, what if they both choose to change their unjust ways? This might be option 2: if both discontinue their unjust practices then they both may have a good harvest but both may not make a profit. However, the victims of injustice will benefit and they will all benefit from not being exiled. However, what if the exile does not occur? What if the threat of exile is actually an impotent threat and does not happen? This is the risk and option 3: if neither person A nor person $\mathrm{B}$ believes that exile is a real threat, neither changes their unjust ways and both continue to make a profit (because of the unjust practices, because the poor will pay for the lost harvest through taxation and recovered mortgages), then they both benefit with continued profits, but the poor do not benefit as they are continued to be exploited. They may choose this option if they determine that the defender of the poor (Yahweh) would not then inflict further hurt on the poor they are defending through this exile, thereby making it an empty threat. However, if the threat of exile is real, then it only takes one person to reject the message of Isaiah and continue in their unjust ways for them all to suffer. 
Which option should the wealthy elite choose? It depends on their motivations (either self-interest or social interest), their theological outlook and their willingness to cooperate. If they are interested in benefitting the community then they will choose to repent from their unjust practices. However, this will most likely result in a loss of their personal profits and a reduction in wealth. However, if only one chooses not to repent, then the entire community will suffer through the threatened exile that will impact all levels of society. However, the rational choice for all involved would be to either both cooperate and change their unjust ways or neither cooperate and risk exile as an empty threat. What a game theory reading of Isaiah 5 highlights is that unjust practices were a choice of the wealthy elite. It highlights the situation as a conflict between individual self-interest and community interest. Within the conflict between interests of the self and those of the community is the willingness to cooperate. Cooperation is essential to obtain the best outcome for both self and community; the decisions made by any one member of a group depend substantially on the decisions made by the other members (King 2007:30). However, individuals may also choose not to cooperate. In this sense, the self-interest of the wealthy elite dominates, as they demonstrate a predisposition towards selfishness. It also importantly makes the implicit options in the text explicit and highlights the rationale of the choices of the wealthy elite. It seems, from the biblical narrative, that the wealthy elite chose the third option. They did not believe the threat of exile was real, and in one sense they were correct as exile was not realised in their own lifetime. However, neither were they motivated by a concern for others within the community who were suffering as a result of their practices and clear choices in rejecting the words of the prophet.

\section{Conclusion}

Utilising the prisoner's dilemma game to make the options that were available to the wealthy elite transparent is helpful, but it can also be unhelpful. We can benefit from the clear presentation of the choices at hand, but we can also be constrained by these same choices. The dilemma is that we can become imprisoned by these options. Perhaps a fourth alternative is possible in which the whole community benefits? Perhaps that alternative is only available in the eschaton where the 'lambs will feed among the ruins of the rich' (Isaiah 5:17). Yet, in the meantime, while we are motivated by the primary concern of self-interest our options will always be pitted in competition one against the other. Game theory has highlighted the conflicts of interest for the wealthy elite of Isaiah 5, albeit in the ambiguous economic environment of 8th-century Judah. The prophet implored those powerful to act mercifully towards the marginalised poor. He appealed to them to overcome self-interest and act in the interest of the community. Yet self-interest prevailed. The wealthy elite did not want to abandon their opulent lifestyle to benefit those less fortunate. This same dilemma is faced by the contemporary community of global readers of the biblical text. The challenge to contemporary readers is to not ignore the global voices of those who suffer as a result of the self-interested lifestyle of the minority. As part of the privileged global community playing prisoner's dilemma in our capitalist economy, will we hear the voice of the prophet Isaiah echo through the ages as he challenges us to choose to discipline our natural self-interest in favour of the common good (King 2007:27)?

\section{Acknowledgements Competing interests}

The author declares that she has no financial or personal relationships that may have inappropriately influenced her in writing this article.

\section{References}

Blenkinsopp, J., 2000, Isaiah 1-39, Anchor Bible, Doubleday, New York, NY.

Barton, J., 1995, Isaiah 1-39, Sheffield Academic Press, Sheffield.

Brams, S.J., 2003, Biblical games: Game Theory and the Hebrew Bible, 2nd rev edn., MIT Press, London, Cambridge, MA.

Brueggemann, W., 1998, Isaiah 1-39, Westminster John Knox Press, Louisville, KY.

Chaney, M.L., 1986, 'Systematic study of the Israelie Monarchy,' Semeia 37, 53-76.

Chaney, M.L., 1999, 'Whose sour grapes? The addressees of Isaiah 5:1-7 in the light of political economy', Semeia 1999, 105-122.

Childs, B.S., 2001, Isaiah: A Commentary, Westminster John Knox Press, Louisville, KY.

Coomber, M.J.M., 2011, 'Caught in the crossfire? Economic injustice and prophetic motivation in Eighth-Century Judah', Biblical Interpretation 19, 396-432. https:// doi.org/10.1163/156851511X595576

Couey, J.B., 2015, Reading the poetry of first Isaiah: The most perfect model of the prophetic poetry, OUP, Oxford.

Faust, A., 2012, The archaeology of Israelite society in iron age II, Eisenbrauns, Winona Lake, IN.

Glass, Z.G., 2000, 'Land, slave labor and law: Engaging ancient Israel's economy' Journal for the Study of the Old Testament 91, 27-39. https://doi. Journal for the Study of the
org/10.1177/030908920002509102

Goldingay, J., 2014, Theology of the Book of Isaiah, InterVarsity Press, Downers Grove, IL.

Holladay, J.S., 1998, 'The Kingdoms of Israel and Judah: Political and economic centralization in the Iron IIA-B (ca 1000-750BCE)', in T.E. Levy (ed.), The archaeology of society in the holy land, pp. 368-398, Leicester University Press, London.

Kaiser, O., 1983, Isaiah 1-12: A Commentary, 2nd edn., Westminster John Knox Press, Louisville, KY.

King, C., 2007, 'What game theory can tell us about saving the world', Stimulus 15(4), 27-33.

Premnath, D.N., 1988, 'Latifundialization and Isaiah 5: 8-10', Journal for the Study of the Old Testament 40, 49-60.

Premnath, D.N., 2003, Eighth century prophets: A social analysis, Chalice Press, St Louis, MI.

Roberts, J.J.M., 2015, First Isaiah: A commentary, Fortress Press, Minneapolis, MN.

Segovia, F.F., 1999, 'Notes towards redefining the postcolonial optic', Journal for the Study of the New Testament 75, 103-114.

Sweeney, M.A., 1996, Isaiah 1-39, with an introduction to prophetic literature, Eerdmans, Grand Rapids, MI.

Watts, J.D.W., 2005, Isaiah 1-33, WBC, Thomas Nelson, Waco, TX.

Williamson, H.G.M., 2006, Isaiah 1-5: A critical and exegetical commentary, T \& T Clark, London, New York. 